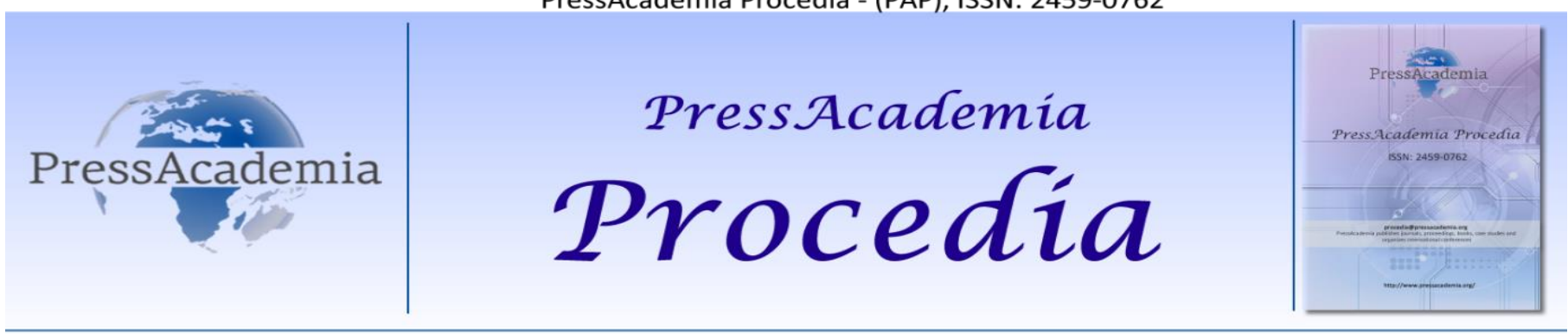

2nd World Conference on Technology, Innovation and Entrepreneurship

May 12-14, 2017, Istanbul, Turkey. Edited by Sefer Şener

\title{
MODERN MACROECONOMIC SCHOOLS THEIR METHODOLOGY, ASSUMPTIONS, CONCLUSIONS, POLICY RECOMMENDATIONS AND RELEVANCE
}

\author{
DOI: 10.17261/Pressacademia.2017.551 \\ PAP-WCTIE-V.4-2017(43)-p.327-335
}

\section{Ozlen Hic Birol}

İstanbul University, Economics Faculy ozlen.birol@istanbul.edu.tr

\section{ABSTRACT}

We attempt to make a comparative evaluation of modern macroeconomic schools: Monetarism and New Classical School based on the Classical System that envisage automatic full employment or natural rate of unemployment (NRU) equilibrium (AFNE or ANRUE) vs. New Keynesian and PostKeynesian Economics based on the Keynesian System which gives unemployment equilibrium (UNE) or non-automatic NRU equilibrium (NANRUE) due to insufficiency of aggregate demand. In order to determine which school is relevant, first the basic assumptions of these systems are compared: i) rational vs. adjusted vs. heterogeneous expectations, ii) existence of perfect competition in all markets leading to flexibility of prices and wages vs. imperfect competition giving rise to rigidities, and iii) presence or lack of coordination between markets. In the final phase of our evaluations the performance of the developed economies are surveyed to establish whether we meet with AFNE or ANRUE or else UNE or NANRUE; and whether policy prescriptions devised by respective schools solve or alleviate the problem at hand when implemented. Our investigations point out that New Keynesian and Post-Keynesian schools are more relevant compared to Monetarism and New Classical School. The choice between New Keynesian and Post-Keynesian Economics, however, is more difficult to make although New Keynesian Economics seems more widespread than Post-Keynesian Economics. Objectively, Post-Keynesian assumptions seem more realistic; normatively, however, New Keynesian stands seems more fit to the present day move towards globalization.
\end{abstract}

Keywords: Modern Macroeconomic Schools, (Neo-)Classical System, Keynesian System, New Keynesian Economics, Post-Keynesian School, Monetarism, New Classical School

JEL Codes: D83, N75, O38, 123

\section{INTRODUCTION}

An attempt will be made in this survey to compare and evaluate modern macroeconomic schools with respect to their methodology, major assumptions, the conclusions they reach concerning automatic full employment vs. unemployment, their consequent policy recommendations and, finally, with respect to their validity and relevance. We will cover Monetarism, New Classical School, New Keynesian and Post-Keynesian Economics, the former two as having stemmed from the Classical System and the latter two from the Keynesian System. This acknowledges Blinder's view [1988] that the dividing line between macroeconomic schools is whether they lead to automatic full-employment equilibrium (AFNE) following the Classical System, or to less-than-full employment or simply unemployment equilibrium (UNE) due to lack of aggregate demand following the Keynesian System. Since modern schools work with "natural rate of unemployment" (NRU) first introduced by M. Friedman [1977], we have replaced fullemployment point with "NRU" and therefore talk about "automatic natural rate of unemployment equilibrium" (ANRUE) for Monetarism and New Classical School and, for the sake of convenience, non-automatic NRU equilibrium (NANRUE) for New Keynesian and Post-Keynesian Economics. The Laffer Curve and Supply Side Economics will not enter our survey because originally it was introduced within the context of Classical (Neo-Classical) Economics and does not qualify as a macroeconomic system on its own. Moreover, it soon became clear that supply side of the economy could be investigated within the context of Keynesian System as well, for instance, as had been done following the stagflation of 1970s [e.g. Gordon: 1977]. Evaluation of the above macroeconomic schools will be made on three planes. The first is "consistency" and "comprehensiveness". This criterion is methodological and draws on criticisms advanced by New Classicals to the Keynesian System that it lacks microeconomic foundations and that its result, UNE is inconsistent with AFNE of traditional microeconomic theory. Traditional microeconomic theory works under the assumptions of perfectly competitive markets and full coordination between markets (Walrasian "auctioneer") and reaches AFNE. This criticism led New Keynesians and also Post-Keynesians to lay the microeconomic foundations 
for Keynesian analysis and UNE (NANRUE). They worked, however, with imperfect markets that lead to price and wage rigidities, thereby to Keynesian insufficient aggregate demand. They also showed that under the absence of the Walrasian auctioneer similar Keynesian results would obtain. We tend to agree along with Post-Keynesians, however, that if it comes to choosing between consistency and comprehensiveness vs. relevance, the latter is the more crucial and useful criterion. Secondly, we will investigate the "realism and validity" of the major assumptions and relationships accepted in the respective macroeconomic schools. For instance, whether statistical investigations confirm the New Classical "Rational Expectations Hypothesis" (REH) or the Monetarist "Adjusted Expectations Hypothesis" (AEH) or else the Keynesian and Post-Keynesian "Heterogeneous Expectations Hypothesis" (HEH) is valid; whether, in actual practice, conditions of perfect competition (PC) or imperfect competition (IC) prevail in markets, and whether there is coordination or lack of coordination between markets (presence or absence of the Walrasian auctioneer). This would clear the way for the third and most important plane of our evaluations and investigations, namely the "validity and relevance" of macroeconomic schools depending on their conclusions and policy recommendations. This means, does the economy reach full employment (FN) or NRU automatically or else does it stop short due to Keynesian lack of demand. Since different schools reach different conclusions, ANRUE or NANRUE, they recommend different economic policies. These policies, in turn, are implemented. Hence the results of these different policy implementations also give us clues as to the validity and relevance of the different macroeconomic schools.

Again following Blinder [1988], we accept here that "the major test is whether a macroeconomic system or school analyses the working of the actual economy correctly, defines the reasons why, if any, an economic problem exists, and whether policies it prescribes to eradicate or alleviate the problem do bear positive results." Thus, for instance, if according to the Keynesian System and hence to the New Keynesian and Post-Keynesian Economics a less-than-full employment situation is explained by lack of aggregate demand, whether we meet with UNE in case of non-intervention of government, and whether Keynesian monetary and/or fiscal policies, if actually implemented had alleviated the unemployment problem encountered. Or else, if according to Monetarism and New Classical School, the economy reaches FN or NRU automatically and we must gauge our monetary and fiscal policies only to prevent inflation, then whether an existing unemployment situation disappears of its own accord within a reasonably short period of time. I would like to stress at this point that the "validity and relevance" of macroeconomic systems and schools is evaluated here exclusively for the developed countries (DCs). No attempt will be made with respect to their validity and relevance for the less developed countries (LDCs) and newly industrializing countries (NICs). Such an investigation could lead to another and different survey on its own. First follows, however, some comments on why we have different macroeconomic schools with widely different conclusions and policy recommendations, taken up in the section below.

\section{DIFFERENCES IN OBJECTIVE AND NORMATIVE ANALYSIS}

The very existence of radically different macroeconomic schools suggest that there are radical differences at the level of "objective" analysis, let alone "normative" differences. New Classical School and Monetarism, based on the Classical System have accepted such assumptions that lead them to ANRUE, hence fundamentally a hands-off policy for the government. New Classicals prescribe a complete hands-off policy. Monetarists, on the other hand, advise only a pre-determined growth in money supply in tune with NNP growth. New Keynesians based on the Keynesian System and also influenced by the earlier "Neo-Keynesians" (e.g. Samuelson, Tobin, Solow, Modigliani, etc.) accept assumptions that lead them to conclude NANRUE or UNE due to Keynesian lack of aggregate demand for the Short-Run (SR) [Blinder: 1988, Mankiw: 1990, Gordon: 1990]. New Keynesians accept the New Classical REH but work with IC markets. They also note the absence of the Walrasian auctioneer. Again in line with Neo-Keynesians, the majority of New Keynesians, excluding those who adhere to the Efficiency Wage and Hysteresis models, conclude that in the Long-Run (LR) the economy will automatically tend towards NRU. Since it will take too long for unemployment to disappear on its own, however, it would necessitate a continuous implementation of Keynesian policies to alleviate it without giving rise to inflation. Post-Keynesians followed Keynes more strictly and were also influenced by the earlier "Orthodox Keynesians" (such as Joan Robinson, Harrod, Kaldor, Shackle, etc.). They accept Keynesian assumptions of uncertainty, HEH in addition to IC and absence of Walrasian auctioneer that lead them to the conclusion of UNE or NANRUE both for the SR and the LR; hence to Keynesian policy prescriptions [Arestis: 1994, Davidson: 1991, 1994]. In the case of the Keynesian System, criticisms leveled against it led to its modification and hence, development. Thus, for instance, Phillips (1958) had challenged Keynes' original belief that by raising aggregate demand we could reach the FN point without giving rise to price increases that are inflationary. But Lipsey (1960) incorporated this criticism into the Keynesian System and thus the Phillips Curve (PC) became a standard tool of the Keynesian System, signifying the choice or trade-off between unemployment and price rises. Similarly, M. Friedman (1977) proposed that in addition to several SRPCs there was a long run and perpendicular PC. The Keynesians incorporated the LRPC into their analysis, not as a perpendicular but still a negatively sloped curve, albeit steeper than the SRPCs. Still further, M. Friedman argued that in view of elasticities involved, monetary policy was effective (in Friedman's case, for one period) and fiscal policy ineffective [Froyen: 1999]. Keynesians broadened their analysis to cover this point; arguing that in times of depression, as Keynes had pointed out, fiscal policy is effective, but at higher income levels, say in recession, monetary policy is the effective tool; and, of course, its effect was not short-lived.

The Efficiency Wage and Hysteresis models devised by some New Keynesians is another example in which we discern an attempt to reach the same conclusion of Keynesians and Post-Keynesians, namely NANRUE for both the SR and the LR. Both Keynes and PostKeynesians, however, work with $\mathrm{HEH}$ and depend mainly on uncertainty and volatility of investments to reach this conclusion. In 
the above models the New Keynesian REH is retained. But, additional assumptions concerning the relation between labor productivity and wages for the case of former models, insider-outsider relations or the relation of labor unions towards its employed members vs. the unemployed in the case of the latter models lead them to the same conclusion of both SR and LR NANRUE [Akerlof: 1984; Yellen: 1984; Katz: 1986, Weiss 1999; Lindbeck and Snower: 1987]. Obviously, however, although the conclusions and policy recommendations of these models are the same as Keynesians, their assumptions and objective analysis is definitely different. Still another major difference is witnessed in the explanation of business cycles particularly as between both New and Post-Keynesians as opposed to Monetarists and New Classicals. The Keynesian schools attribute business cycles to Keynesian lack of effective demand and volatility of investments. They therefore prescribe Keynesian demand management policies to curb it. Monetarists explain business cycles with mismanaged monetary policies, an argument which may be traced back to Alfred Marshall (1923). This has led Monetarists to advise a non-discretionary monetary policy. New Classicals, on the other hand, explain business cycles as optional responses of the economy to technological change [Barro: 1981; Barro and King: 1984, Lucas: 1987]. Hence, a hands-off policy should continue; nothing should be done to redress them. Looking at it from another angle, the above indicates that despite the vast academic give-and-take and econometric analysis, wide differences in the objective analysis offered by different schools still exist and need an explanation. The different results reached at the stage of objective analysis basically stem from the fact that economics is a "social" science. Unlike natural sciences, controlled experiments in social and economic phenomena are impossible. But for a given country at a given time, so many factors affect actual outcome that despite powerful statistical and econometric tools, different people or schools may be led to different results and interpretations. Secondly, in observing and interpreting economic phenomena, a researcher may come under the influence of his/her pre-conceived philosophical and political preferences.

To quote one relatively recent example, investigating the data of 1970s, New Classicals, Lucas and Sargent [1978] concluded that the PC had collapsed; hence the Keynesian System was wildly incorrect. But New Keynesians, Gordon [1977, 1985], Ando and Kennickel [1985] and others showed that the PC had not collapsed. It was merely shifting upward because of stagflation and cost and price increases during the period studied. In addition to the "objective" there are also "normative" differences between different individuals, groups or schools leading to different policy prescriptions based on the same objective analysis. This covers a host of value judgments such as: can governments devise and implement correct policies; how much weight do we attach to improvements in income distribution; what would be our choice between price rises vs. reducing unemployment; etc. For instance, a few New Keynesians, despite their objective analysis and conclusion of NANRUE, refrain from recommending that governments implement (Keynesian) policies because they fear that governments often make mistakes in implementing them, hence give rise to greater problems than those they set out to alleviate. As another example, Post-Keynesians, in their objective analysis, argue about "conflict of interests between social groups" rather than "harmony" as conceived by the Classicals. In their policy recommendations Post-Keynesians also normatively give greater weight to improving income distribution compared to even, the majority of New Keynesians, not to mention the Classicals. The choice between price increase and unemployment rate on the SRPC and LRPC is another well-known case where our value judgments come into play. Falling back to "coarse-tuning" from the more ambitious "fine-tuning" is a question concerned with objective analysis, and not normative. Based on their objective and normative analyses, hence their policy recommendations, New Classicals and Monetarists, along with Classicals, take their place at the right side of the political spectrum. Keynesians spread from center to center left, some to the left. New Keynesians spread from center right to center left. Post-Keynesians, on the other hand, spread from center left to the left.

\section{METHODOLOGY: CONSISTENCY AND COMPREHENSIVENESS}

The methodological question of consistency and comprehensiveness had been brought to our attention particularly with the criticisms of New Classicals directed at the Keynesian System that it lacked microeconomic foundations and its result, UNE was inconsistent with that of traditional microeconomic analysis, AFNE. Certainly, a perfect macroeconomic system or paradigm will have to be consistent and comprehensive and New Classicals were right in their methodological criticism of Keynesian System [Coddington: 1976]. But, one must accept that Keynes published his General Theory in 1936, immediately after the 1929-34 Great Depression and the world was in dire need of finding a remedy to the depression, unemployment and business cycles. This was, among many others, one major area in which the Classical System and the Classical remedy of lowering the wage rate had failed miserably. Keynes' alternative macroeconomic system and its policy recommendation, raising public expenditures gave positive results. In fact, many economists before Keynes had advocated raising public expenditures to alleviate the depression and the unemployment problem. But Keynes had backed it with a viable macroeconomic system [Blaug: 1985]. It is unfair to criticize Keynes for not having dived into microeconomic foundations of all the macro concepts and relationships he introduced because, given the grave and pressing problems that needed immediate cure, he simply had no further time to spend. In fact, many of his concepts and relationships between macro variables were not tested econometrically. What is remarkable is that econometric researches carried out later confirmed the accuracy of such concepts and relationships as the consumption function, liquidity preference, marginal efficiency of investment, and low interest elasticity of the investment function [Ackley: 1963].

We definitely witnessed a Keynesian Revolution [Klein: 1961]. We had a macro system completely different from the Classical, that gave UNE and not AFNE, and Keynesian recipes worked positively up until the stagflation of the 1970s. During the 1970s, however, Keynesian System came under attack both by Monetarists and New Classicals. The New Classicals, while arguing ANRUE will prevail 
and not Keynesian UNE, also charged that Keynes' macro analysis lacked micro foundations and its conclusion, UNE, was, in fact, inconsistent with the AFNE conclusion of (traditional) microeconomic analysis. New Classical criticism is definitely a valid methodological point and New Keynesians, in trying to revalidate the Keynesian System and UNE (NANRUE), discarded the traditional microeconomic analysis that worked with PC in all markets, full-flexibility of Prices (Ps) and Wages (Ws) and perfect coordination between markets. Instead, they accepted IC, which gave rise to P and W rigidities, hence to Keynesian lack of aggregate demand leading to NANRUE. Thus, Keynesian macro analysis was supplied with microeconomic foundations and the system became consistent and comprehensive. Similarly, Post-Keynesians also worked with IC markets and absence of Walrasian auctioneer. But they rejected REH, accepted Keynesian HEH and uncertainty and thus came to the Keynesian conclusion of UNE (NANRUE) both for the SR and the LR. Though consistency and comprehensiveness is an important methodological point, the real test for choosing between alternative schools is in determining which is valid and relevant [Davidson: 1991]. This question is taken up in the following section.

\section{REALISM OF THE BASIC ASSUMPTIONS BEHIND THE MACROECONOMIC SCHOOLS}

The decisive criterion in choosing a macroeconomic system, school or paradigm is whether it diagnoses the working of the economy and a given economic problem that has arisen correctly, giving the correct reasons why the economies work the way they do, or why a particular problem has arisen; and hence, whether its policy recommendations when implemented will eliminate or alleviate the problem at hand. We call this criterion "validity and relevance", or else, a test whether the macroeconomic school at hand is "realistic". In short, validity and relevance opens the way for the usefulness of the macroeconomic school for the society. We will evaluate the validity and relevance of the four modern macroeconomic schools on two planes. In the first plane, we will investigate the various research carried out on the realism and validity of the basic assumptions accepted by the respective schools. It is hard to imagine a macroeconomic school to arrive at correct conclusions with regard to the working of the economy if the basic assumptions it works with are unrealistic and not confirmed by actual facts. On the second and final plane we will investigate whether the actual course the economies take and the problems encountered conform with the conclusions of respective schools, and if and when the policy recommendations of a particular macroeconomic school are actually implemented they have alleviated the problem at hand and altered the course of the economy for the better. We will take up here three basic assumptions, the first concerning "expectations", the second concerning "market structure", hence "P and W rigidities" and the third "coordination between markets" or existence of a Walrasian auctioneer.

\section{VALIDITY OF ASSUMPTIONS CONCERNING EXPECTATIONS}

On expectations in the two basic macroeconomic systems, the Classical and the Keynesian, the Classicals had assumed that workers as well as entrepreneurs estimated future Ps correctly. Keynesians, however, accepted that only entrepreneurs' price expectations were accurate; the workers generally under-estimated future price rises and demanded a lower nominal wage increase, giving rise to a fall in the real wage. This is a crucial assumption because in the Classical System when workers raise their Ws at the same ratio as Ps, the real wage will remain the same; an increase in Money Supply (Ms) or aggregate demand will have only raised Ps. Since according to Classicals the economy is already at the FN point, this merely means inflation. For the Keynesian System, an increase in Ms or aggregate demand would give rise to both an increase in output and employment as well as some increase in Ps since the economy is assumed to be at UNE. Followingly, the New Classicals, taking heed from Muth [1960, 1961] have developed the Classical assumption into "Rational Expectations Hypothesis: REH" [Lucas and Rapping: 1969, Lucas: 1970, and others]. This means all economic agents are rational, optimizing and maximizing; they all have access to full information for the decisions they will take and they will predict future Ps correctly, hence make correct, i.e. optimizing and maximizing decisions. REH also entails that for future to be predicted accurately we should "not have uncertainty" and that "history should repeat itself", i.e. the same set of conditions met in the past should produce the same set of results in the future [Davidson: 1991, 1994]. Surely, some agents may make mistakes in their expectations but it is important that these mistakes will not be systematic; hence they will cancel each other. Moreover, if the economic agents know beforehand that the government will implement a given monetary or fiscal policy when future Ps, employment, etc. take certain magnitudes, the agents when making their final decision will also take into account the effects of these government policies as well, since they will also know exactly how much these policies will affect the magnitudes of the parameters. This will nullify the effectiveness of any predictable government policy. Thus, in effect, in the New Classical School REH institutes "Neutrality of Money", "Dichotomy" and "Say's Law" immediately or in the same period.

Friedman [1970] and Monetarists came up with a novel assumption: "Adaptive Expectations Hypothesis: AEH" which assumes that the workers, when Ms is increased and future prices rise will err in the first period and keep their Ws the same; but in the next period they will realize the exact magnitude of the price rise and the fall in their real wage, hence will raise their Ws correspondingly. Thus, the effects of monetary policy (Ms increase) in reducing unemployment below NRU point will live only for one period; the economy will return to NRU and Ms increase will have only raised Ps and Ws; with the value of real parameters the same as one period ago [text book explanations: Branson: 1989, Froyen: 1990, Blaug: 1985]. Thus AEH institutes "Neutrality of Money", "Dichotomy" and "Say's Law" one period later. In effect, both New Classicals and Monetarists reach Classical conclusions, one working with REH, the other with AEH. New Keynesians have also accepted "REH", which is obviously contrary to the Keynesian assumptions in this regard, namely, systematic under-estimation of future Ps on the part of workers, as well as uncertainty and non-ergodicity. There were two reasons why New Keynesians accepted REH. One was they needed to enter into arguments and 
discussions with New Classicals in the 1970s when New Classicals and Monetarists had gained ground in the academic circles during the 1970s [Blinder: 1985; Klamer: 1984]. Secondly, Fischer [1977] and Taylor [1980] had already proved that P and W rigidities were more important in giving rise to UNE or NANRUE than REH because in the models they devised, REH plus $\mathrm{P}$ and W rigidities still gave rise to Keynesian lack of aggregate demand and unemployment which, in turn, could be remedied by implementing Keynesian demand management. Post-Keynesians, on the other hand, were more faithful to the original Keynesian assumptions and scornful not only towards New Classicals but also towards New Keynesians for having accepted non-Keynesian assumptions [Arestis: 1994, Davidson: 1991, 1994; and others]. Therefore, Post-Keynesians presented their assumptions in this regard as "Heterogeneous Expectations Hypothesis: $\mathrm{HEH}^{\prime \prime}$ which is exactly the same as Keynes' assumptions. According to Post-Keynesians, entrepreneurs are in a better position than workers to obtain full information and estimate future Ps correctly. The workers are less knowledgeable and generally end up under-estimating future Ps. It is difficult to carry reliable research to determine directly which of the above assumptions is valid and correct. But the scanty research made in this field [e.g. Rotemberg: 1984, Lowell: 1986] point out to the possibility that $\mathrm{HEH}$ may be more realistic compared to (AEH and) REH though the latter is theoretically a very tidy construct.

\section{VALIDITY OF ASSUMPTIONS CONCERNING MARKET STRUCTURE}

New Classicals and Monetarists have accepted the traditional microeconomic analysis based on perfect competition (PC) in all markets, including the labor market. This again follows the Classical System and its assumptions. Since a PC market with "homogeneous products" and "many sellers and many buyers" is seldom encountered in many economies today, this assumption must be interpreted as follows: "competition" should be a very powerful factor in all markets such that it should lead to "full flexibility of Ps and Ws". It is this full flexibility of Ps and Ws that is crucial for AFNE or ANRUE. Both New Keynesians and PostKeynesians, in contrast, have discarded traditional microeconomic analysis based on PC and instead have accepted that imperfect competition (IC) prevails in all markets of the economy. This means that the markets are either in "monopolistic competition" or are "oligopolistic" with competition prevailing and with absence of trusts and cartels. It is easier to observe that IC is the more realistic assumption compared to PC. Firstly, we have generally differentiated products in all the manufacturing and services sectors. In addition, "concentration ratios" can be calculated to determine whether the market is in monopolistic competition or oligopolistic, or else oligopolistic with one or few price leaders. The telling point here is that IC will give rise to P and W rigidities, however temporary, and these, in turn, will give rise to Keynesian lack of aggregate demand leading to UNE or NANRUE.

Several models have been constructed by New Keynesians and Post-Keynesians in which IC markets will give rise to P and W rigidities and, in turn, to Keynesian insufficient aggregate demand. To name only a few, we may cite "Menu Costs Model" [Mankiw: 1985, Akerlof and Yellen: 1985], "The Staggering of Wages and Prices" [Fischer: 1977, Taylor: 1980], "Imperfect Information and Staggered Wages" Ball and Cecchetti: 1980], "Credit Rationing Under Imperfect Information" [Stiglitz and Weiss: 1981], "Price Level Inertia" [Blanchard: 1983], "Monopolistic Competition" [Blanchard and Kiyotaki: 1987], etc. The list is illustrative and not comprehensive and systematic. More information on New Keynesian models can be obtained from Mankiw and Romer Vol. 1 and Vol. 2 [1991], Blinder [1985] and Gordon [1990]. Most of these models are mutually inclusive; one may be operative at a given sector and a given time in a given country, the other at another sector at the same or a different time. Though, taken by itself, one single model may not cause $\mathrm{P}$ and $\mathrm{W}$ rigidities of enough magnitude to create a serious slack, all taken together with their combined effects spread over time would go a long way to explain and account for unemployment caused by Keynesian insufficient aggregate demand. Interpreted this way, New Keynesian and Post-Keynesian assumption of imperfectly competitive markets giving rise to $\mathrm{P}$ and $\mathrm{W}$ rigidities seems more realistic compared to the New Classical and Monetarist assumption of full flexibility of Ps and Ws.

\section{VALIDITY OF ASSUMPTIONS CONCERNING COORDINATION BETWEEN MARKETS AND WALRASIAN AUCTIONEER}

The third assumption concerns coordination between markets. In the traditional microeconomic theory and following Walras' general equilibrium analysis not only the markets should all be perfectly competitive with full flexibility of Ps and Ws but all the markets should adjust immediately not to leave any over or under supply or demand in any market. This is likened to the presence of an auctioneer, called the "Walrasian auctioneer" who organizes and arranges so that the Ps and Ws that will clear all the markets will be bid and arrived at immediately and simultaneously. New Classicals, working with traditional microeconomic analysis and Walrasian general equilibrium, have accordingly also accepted the presence of the Walrasian auctioneer. Leijonhufvud [1973] was the first to argue that we did not have full coordination of all the markets, such that even if all markets were PC, there would still be lags in the adjustment of Ps and Ws to clear all the markets. Hence some would remain uncleared; there would be spillovers, giving rise to Keynesian insufficient aggregate demand and UNE. Though Leijonhufvud erred by placing too much weight on lack of coordination between markets in interpreting Keynes [Blaug: 1985], this certainly is still one important reason why we may not have AFNE at least immediately but face UNE in the SR. Both New Keynesians and Post-Keynesians who have accepted IC in most markets, hence $\mathrm{P}$ and $\mathrm{W}$ rigidities stemming from IC conditions, have also rejected the assumption of Walrasian auctioneer. Therefore, according to them, we may meet with Keynesian UNE (NANRUE) due to lack of coordination between markets as well as due to $\mathrm{P}$ and $\mathrm{W}$ rigidities because of IC markets. Empirical observations suggest that the assumption of lack of coordination between markets, that is, absence of Walrasian auctioneer is a more realistic assumption than that of immediate and simultaneous coordination. 


\section{CONCLUSION: VALIDITY AND RELEVANCE OF MODERN MACROECONOMIC SCHOOLS}

Although modern macroeconomic schools start with the years 1970s, in order to assess their validity and relevance we need to take as long span of time as possible, hence we should go as far back as the Industrial Revolution, the emergence of economics and the Classical System (in the 3rd quarter of 18. Century). The acid test is whether DCs display AFNE or ANRUE as argued by the Monetarists and New Classicals based on the Classical System; or else UNE or NANRUE as argued by the New Keynesians and PostKeynesians based on the Keynesian System. And consequently whether the hands-off policy recommendation of the former works, with the economy having reached AFNE (ANRUE) and price stability is attained; or else we have UNE or NANRUE and Keynesian demand management works, unemployment problem is alleviated, going up to the point at which price rises are inflationary. We are neglecting at this stage of our evaluations whether UNE (NANRUE) is witnessed only in the SR as is argued by New Keynesians in general, or both in the SR and in the LR as is argued by the Keynesians as well as Post- Keynesians and those New Keynesians who accept the Hysteresis and Efficiency Wage models. Viewed in this light, historical observations suggest that Keynesian UNE or New Keynesian and Post-Keynesian NANRUE are definitely more valid and relevant. This is because since the Industrial Revolution up to the 1929-34 Great Depression and the 2.W.W 1939-44, the world continuously witnessed unemployment and business cycles; hands-off policy advocated by the Classicals was of no avail. Similarly, of no avail was the Classical policy suggestion that wages should be lowered and the influence of labor unions or government intervention on wages should be removed. In contrast, when Keynesian monetary and fiscal policies were implemented all throughout the period starting with the 2.W.W, its aftermath and till the 1970s, the world witnessed rapid and steady economic growth, curbing of business cycles, alleviation of the unemployment problem, and relative price stability. Surely there were other factors that contributed very significantly to rapid and steady growth, such as free international trade policies, international aid and credit followed after the 2.W.W.; but the implementation of Keynesian policies was also definitely instrumental. The problems that were faced during this period emanated from balance of payments deficits, the peculiarities of the international monetary system implemented during the period, and the reluctance of governments towards devaluation. Therefore, these problems had nothing to do with the validity and relevance of the Keynesian System. On the contrary, they could be explained within the context of the Keynesian System.

Thus, since 1936 and up until 1970s we witnessed a "Keynesian Revolution" as Klein had noted. Keynesian System was "mainstream" both in the academic circles and also in the field of implementation, bearing positive results. Keynesian System as mainstream needs, however, to be dissected more deeply. "Orthodox Keynesians" in the UK adhered more strictly to the Keynesian assumptions and conclusions. "Neo Keynesians" in the USA tended to accept the long run tendency of the economy towards automatic FN. Hence, in their arguments with Neo-Classicals (Pigou, Patinkin) they were ready to arrive at the Neo-Classical Synthesis (NCS). We have overlooked here this important theoretical difference because according to the interpretation of NCS by Neo-Keynesians, the economy would frequently fall to Keynesian unemployment in the SR and this necessitated de facto continual implementation of Keynesian policies. Again, since the 1950s M. Friedman was trying to reinstitute the Classical Quantity Theory [Friedman: 1956; Friedman and Meiselman: 1959; Friedman and Schwartz: 1965]. But he had remained a dissenting and minority opinion during this period up until the 1970s. What is important from our perspective here is that the diagnosis, conclusions and policy implementation of the Classical System since the Industrial Revolution up till the Great Depression failed. In contrast, implementation of the Keynesian policies bore positive results from the time of Great Depression up to the 1970 s. The years 1970 , on the other hand, witnessed a severe stagflation. Although Keynesian policies continued to be implemented at low-key, it was obvious that Keynesian policies alone could in no way negate the stagflation at hand. This is because the root of the problem had nothing to do with the behavior of the aggregate demand; it stemmed from the monopolistic practice of raising the prices and reducing the production of petroleum by OPEC. Although it may be hard to prove econometrically, we could say that a Classical "hands-off" policy at the time could have worsened the situation. But, we are disinclined to make a definitive judgment of the years 1970s concerning the relevance of macroeconomic schools because of ambiguities involved concerning the evaluation of alternative policy recommendations. Nonetheless, during the years 1970s, the Keynesian System fell precipitously from favor in the academic circles. Amongst the younger, the New Classical Economics was widely spread, called the "Counter Revolution" [Blinder: 1985; Klamer: 1984]. Monetarism also became fashionable and Monetarists called it the "Monetarist Counter Revolution" [Froyen: 1990]. Thus, during 1980s economic policies implemented were in line with Monetarism and New Classical School. Government intervention was reduced, including demand management, and Monetarist tight money was implemented in the face of recession. The purpose of the latter policy was to attain price stability while, it was believed, the economy would come to NRU automatically within a short period of time. This, however, did not come to happen; the recession and unemployment was prolonged both in Europe and the USA. Therefore, the years 1980 s can be cited as another evidence which has indicated that Monetarism and New Classical economics was not relevant and implementation of policies in line with the above schools did not give positive results [Blinder: 1985].

During the years 1980s, in view of the perceived failures of Monetarist and New Classical policies, Keynesian economics became once more mainstream in the academic circles (Counter-Counter Revolution). In the early years of the decade in the USA, endeavors to meet the methodological criticisms of the New Classicals and also to open up discussion channels with them, Keynesianism took the form labelled New Keynesian Economics, with assumptions and conclusions dwelt before. Basically in the UK, but with participation of some notable American economists, by mid 1980s Post-Keynesian Economics took shape, with assumptions and conclusions much more in line with Keynes. During the 1990s up to the present, there was a return to basically 
Keynesian discretionary monetary policies, with lesser recourse to the implementation of fiscal policies on account of several drawbacks involved. During the same period up to the most recent years, the world and, in particular, the USA witnessed this time relative economic growth, alleviation of the unemployment problem accompanied with relative price stability. Thus, the years 1990 s can be taken as still another indication that Keynesian economics and not the Classical System and modern schools based on the Classical System were valid and relevant. One qualification, however, needs to be made at this point. Since 1990 s the world entered a milieu or a process of globalization and international competition. This necessitated "conservative policies"; maintaining price stability became important, hence government budget deficits were reduced or eliminated. Similarly, international competition forced European countries as well as Japan to curb excessive social benefits, to cut labor costs and to introduce greater flexibility to labor markets and unemployment. These measures or efforts should in no way be considered as un-Keynesian; they emanated from the need to face international competition and not from any negative aspect of the Keynesian System. Indeed, they too could be explained within the context of the Keynesian System. We may, however, acclaim that the present globalization trend is basically an outgrowth of Ricardo's "comparative advantage" and his case for free trade. The most recent recessionary tendency in the USA, following a long period of steady growth is tried to be brought under control, again in major part by Keynesian discretionary monetary policy. Institutional arrangements and rules set by the Maaschrict Treaty and the Euro, on the other hand, make it much harder for the euro members of the European Union to implement Keynesian monetary as well as Keynesian fiscal policies. Thus, there is fear that recession in the Euro area would be more prolonged. This also implies that in prolonged recessions, Keynesian monetary policy may not be adequate and should be supplemented with fiscal policies. The above bird's eye view survey of the results obtained from the policy implementations of various macroeconomic schools during a very long span of time since the Industrial Revolution up to the present definitely proves that the Keynesian System, that is, New Keynesian and Post-Keynesian Economics is valid and relevant compared to Monetarism and the New Classical Schools based on the Classical System. It is harder to decide, however, between the New Keynesian and Post-Keynesian Economics if we simply focus our attention on observations of UNE or NANRUE only for the SR or both for the SR and the LR. The first is the general belief of New Keynesians excepting those who adhere to Hysteresis and Efficiency Wage models. They assert that in the LR the economy would tend toward ANRUE. PostKeynesians and Super-Keynesian models, on the other hand, believe that the economy would give NANRUE both in the SR and in the LR. But many New Keynesians (e.g. Blinder) assert that this is more of a theoretical point because in actual practice we would continually face NANRUE in the SRs and continually implement Keynesian demand management policies. This would not allow us to witness whether the economy tends towards ANRUE in the LR. All we can say definitively is that even if the economy tends towards ANRUE in the LR, as recent experience in 1980s show, it simply takes too much time to bear unemployment for such a long period of time. But this is the time-honored proposition put forth during the arguments on NCS between Neo-Classicals and NeoKeynesians. There is one interesting point, however, that seems to work in favor of the New Keynesian Economics and against the Post-Keynesian Economics during the more recent times. The milieu of globalization requires that "conservative" policies should be implemented, price stability maintained and excessive social benefits curbed. One needs to make the distinction in this regard, however, between "objective" and "normative" aspects of Post-Keynesian economics. Though direct observation whether the economies tend toward ANRUE in the LR is hard to come by, as a substitute we may evaluate the validity of assumptions behind the Post-Keynesian vs. New Keynesian Economics. In doing so, we may come to the conclusion that assumptions behind Post-Keynesian Economics are more realistic compared to those behind New Keynesian Economics. For instance, we may agree in our objective analysis, that $\mathrm{HEH}$ is more realistic than REH, that future is uncertain and cannot be predicted with accuracy, that both national and international institutions, hence politics play an important role in defining economic decisions, and that conflict of interest and not harmony dominates the area of income distribution. But, what is also at stake here is the normative value judgments of most of the Post-Keynesians who assign a greater importance to income distribution and to the goal of improving of income distribution. The present conditions of the world economy do not seem fit for such a value judgment in defining economic and social policies. In fact, in the present milieu of globalization many European countries and Japan found themselves with excessive social benefits and labor costs carried up until today from their historical past. This necessitates policies of curbing these excessive social benefits and injecting greater flexibility to the labor market and employment, and not the other way round, in order to attain higher growth and increased employment. This fact should lead us, at least normatively, in favor of the New Keynesian Economics compared to the Post-Keynesian Economics. Or else, on the objective plane we may still choose to be Post-Keynesian but normatively make due allowance in the weight that we assign to improving income distribution via welfare measures for the special case we face presently in Europe and Japan. We may conclude here by observing that both in the USA and much of the European countries New Keynesian Economics seems to have taken greater hold compared to Post-Keynesian Economics, while Post-Keynesian Economics seems to be on the demise [Dunn: 2000].

\section{REFERENCES}

ACKLEY, Hugh Gardner: Macroeconomic Theory. Macmillan Co., 1963. 
AKERLOF, George: “Gift Exchange and Efficiency Wage Theory: Four Views,” AER, No. 74, May 1984.

, and YELLEN, Janet L.: “A Near-Rational Model of the Business Cycles with Wage and Price Inertia,” QJE, No. 100 supplement, 1985.

ANDO, Albert F., KENNICKELL, Arthur: "Failure of Keynesian Economics and 'Direct' Effects of Money Supply: A Fact or a Fiction," University of Pennsylvania, mimeo, 1985.

ARESTIS, Phillip: The Post-Keynesian Approach to Economics: An Alternative Analysis of Economic Theory and Policy. Edward Elgar Publishing Ltd., 1994.

BALL, Laurence B., and COCCHETTI, Stephen, G.: “Imperfect Information and Staggered Price Setting,” AER, Dec. 1988.

BARRO, Robert J.: Money Expectations and Business Cycles: Essays in Macroeconomics. Academic Press, 1981.

, and KING, Robert G.: “Time-Separable Preferences and Inter-Temporal Substitution Models of Business Cycles,” QJE, Nov. 1984.

BLANCHARD, Oliver J.: "Price Asynchronization and Price Level Inertia," Inflation, Debt, and Indexation. Ed. by Rudiger Dornbush, Mario Henrique Simonsen, The MIT Press, 1983.

, and KIYOTAKI, Nobuhiro: “Monopolistic Competition and the Effects of Aggregate Demand," AER, Vol. 77, No. 4, Sept. 1987.

BLAUG, Marc: Economic Theory in Retrospect. Cambridge University Press, 1985.

BLINDER, Alan S.: “The Fall and Rise of Keynesian Economics," Economic Record, Vol. 64, No. 187, Dec. 1988.

BRANSON, William H.: Macroeconomic Theory and Policy. Harper and Row, 1989.

CODDINGTON, Alan: “Keynesian Economics: The Search for First Principles,” JEL, Dec. 1976.

DAVIDSON, Paul: Controversies in Post-Keynesian Economics. Edward Elgar Publishing Ltd., 1991. $\overline{1994 .}$

: Post-Keynesian Macroeconomic Theory: A Foundation for Successful Economic Policies for the 21st. Century. Edward Elgar Publishing Ltd.,

DUNN, Stephen P.: “Wither Post Keynesianism,” JPKE, Vol. 22, No. 3, Spring 2000.

FISCHER, Stanley: “Long-term Contracts, Rational Expectations and the Optimal Money Supply Rule,” JPE, Vol. 85, No. 1, Feb. 1977.

FRIEDMAN, Milton: “Inflation and Unemployment: New Dimension in Politics," JEL, June 1977.

: "Quantity Theory: A Restatement," Studies in the Quantity Theory of Money. Ed. by Milton Friedman, University of Chicago Press, 1956.

and MEISELMAN, David: "The Relative Stability of Monetary Velocity and the Investment Multiplier in the United States, 1897-1958,"

Commission on Money and Credit, 1959.

, and SCHWARTZ Anna: The Great Contraction. Princeton University Press, 1965.

FROYEN, Richard T.: Macroeconomics. Macmillan Co., 1990.

GORDON, Robert J.: "Can Inflation of the 1970s Be Explained," Brookings Papers on Economic Activity, Vol. 8, No. 1, 1977.

: “Understanding Inflation in the 1980s," Brookings Papers on Economic Activity, 1985.

: "What is New Keynesian Economics," JEL, Vol. XXVIII, Sept. 1990.

HOLT, Richard: “Looking Ahead: The Future of Post-Keynesian Economics," www.cfs.colorado.edu.

KATZ, Lawrence: “Efficiency Wage Theories: A Partial Evaluation,” NBER Macroeconomics Annual, 1986.

KLAMER, Arjo: The New Classical Macroeconomics, Conversations with the New Classical Economists and their Opponents. Harvester Press, 1984.

KLEIN, Lawrence Robert: The Keynesian Revolution. McMillan, 1961.

LEIJONHUfVUD, Axel: On Keynesian Economics and the Economics of Keynes: A Study in Monetary Policy. Oxford University Press Inc., 1973.

LINDBECK, Assar, SNOWER, Dennis: “Wage Setting, Unemployment and Insider-Outsider Relations,” AER, No. 76, May 1986.

LIPSEY, Richard G.: "The Relationship between Unemployment and the Rate of Change of Money Wage Rates in the United Kingdom, 1861-1957: A Further Analysis," Economica, No. 27, Feb. 1960.

LOWELL, Michael E.: "Tests of Rational Expectations Hypothesis," AER, March 1986.

LUCAS, Robert E.: “Econometric Policy Evaluation: A Critique,” Ed. by Brunner, Meltzer, The Phillips Curve and the Labor Markets, CarnegieRochester Conference Series on Public Policy, No. 1, Amsterdam, North-Holland, 1976.

: Models of Business Cycles. Blackwell, 1987.

: "Price Expectations and the Phillips Curve," AER, June 1970.

RAPPING, Leonard A.: “Real Wages, Employment and Inflation,” JPE, Sept. 1969. 
and SARGENT, Thomas: "After Keynesian Macroeconomics," After the Phillips Curve: Persistence of High Inflation and High Unemployment, Federal Reserve Bank of Boston Conference Series, No. 19, 1978.

MANKIW, N. Gregory: “A Quick Refresher Course in Macroeconomics," JEL, Vol. XXVIII, Dec. 1990.

: "Small Menu Costs and Large Business Cycles: A Macroeconomic Model of Monopoly," QJE, Vol. 100, No. 2, May 1985.

and ROMER, David: New Keynesian Economics, Volume 1. The MIT Press, 1995.

and : New Keynesian Economics, Volume 2. The MIT Press, 1995.

MUTH, John F.: “Optional Properties of Exponentially Weighted Forecasts," Journal of the American Statistical Association, No. 55, 1960.

: "Rational Expectations and the Theory of Price Movements," Econometrica, July 1961.

PHILLIPS, Albon William H.: "The Relation between Unemployment and the Rate of Change of Money Wage Rates in the United Kingdom, 18611957," Economica, No. 25, Nov. 1958.

ROTEMBERG, Julio J.: “Interpreting Some Statistical Failures of Some Rational Expectations Macroeconomic Models,” AER, No. 74, 1984.

STIGLITZ, Joseph E., and WEISS, Andrew: “Credit Rationing in Markets with Imperfect Information,” AER, June 1981.

TAYLOR, John B.: “Aggregate Dynamics and Staggered Contracts," JPE, Vol. 88, No. 1, Feb. 1980.

WEISS, Andrew: Efficiency Wages: Model of Unemployment, Layoffs and Wage Dispersion. Princeton University Press, 1990.

YELLEN, Janet E.: “Efficiency Wage Models of Unemployment,” AER, No. 74, May 1984. 